\title{
Prevalence of HIV infection among high-risk groups in Iran: a systematic review and meta-analysis
}

\author{
Shahrzad Nematollahi ${ }^{1}$, Erfan Ayubi ${ }^{2}$, Yousef Moradi ${ }^{3}$, Amir Almasi-Hashiani ${ }^{4}$, Kamyar Mansori $^{5}$, \\ Ensiyeh Jenabi ${ }^{6}$, Salman Khazaei ${ }^{6}$
}

${ }^{1}$ Men's Health and Reproductive Health Research Center, Shahid Beheshti University of Medical Sciences, Tehran, Iran ${ }^{2}$ Zahedan University of Medical Sciences, Zahedan, Iran

${ }^{3}$ Kurdistan University of Medical Sciences, Sanandaj, Iran

${ }^{4}$ Arak University of Medical Sciences, Arak, Iran

${ }^{5}$ Zanjan University of Medical Sciences, Zanjan, Iran

${ }^{6}$ Hamadan University of Medical Sciences, Hamadan, Iran

\begin{abstract}
Introduction: In Iran, data relating to an updated prevalence of human immunodeficiency virus (HIV) infection among high-risk groups are lacking. Therefore, this study aimed to determine the prevalence of HIV infection among high-risk groups in Iran through meta-analyses.

Material and methods: Electronic scientific databases, including PubMed, SCOPUS, and Web of Knowledge were explored to identify relevant studies. Random effect model was used to estimate the pooled prevalence.

Results: A total of 1,113 records were identified in initial search, out of which 43 reports were finally included in the study. The estimated overall prevalence among high-risk groups was $0.06 \%$, which ranged from 0 among drug addict prisoners in the North to 0.2 among drug addicts in the South of Iran.

Conclusions: Prevalence of HIV among high-risk groups in Iran is relatively low. The prevalence of HIV in high-risk groups in different parts of Iran has a different pattern. Due to significant prevalence of HIV in injecting drug users compared to other high-risk groups, there is a need to pay serious attention to this high-risk group and adopt preventive strategies.
\end{abstract}

HIV AIDS Rev 2021; 20, 1: 1-9

DOI: https://doi.org/10.5114/hivar.2021.105107

Key words: HIV, prevalence, drug users, sex workers, prisoners, meta-analysis, Iran.

\section{Introduction}

Risky behaviors, such as substance abuse, alcohol consumption, high speed driving, attempting/committing suicide, and illegal sexual contacts are considered major health problems worldwide. Unfortunately, unhealthy and risky

Address for correspondence: Salman Khazaei,

Hamadan University of Medical Sciences,

e-mail: Salman.khazaei61@gmail.com

behaviors are increasing, causing a serious concern for community health and policymakers [1]. Among them, illegal injection drug use (IDU) and unsafe sex with infected partner or sex with multiple partners are two of the most common routes of transmission for hepatitis B virus (HBV),

Article history:

Received: 21.01.2020

Received in revised form: 10.02.2020

Accepted: 01.09.2020

Available online: 30.03 .2021
International Journal of HIV-Related Problem

HIV \& AIDS

R e v i e w 
hepatitis $\mathrm{C}$ virus (HCV), and human immunodeficieny virus (HIV) [2].

Nowadays, HIV infection is estimated to occur in 40 million chronic cases around the world [3]. But the prevalence of this disease differs in various sub-groups of population as compared with general population; for example, in a study conducted in Chennai, India, the prevalence of HIV among IDUs was $29.8 \%$ [4], whereas in Miami, Florida, the prevalence of HIV among sex workers was $22.4 \%$ [5]. Results on the review from 75 low-income and middle-income countries revealed that in 10 countries, the prevalence of HIV among prisoners was greater than $10 \%$ [6].

The estimated prevalence of HIV infection in the general population of Iran is $<0.2 \%$ [6], but in high-risk groups, the prevalence rate is much higher. In Tehran, capital of Iran, results of a study indicated that the prevalence of HIV among male injecting drug users was $23.5 \%$ [7]. Kazerooni et al. found that prevalence of HIV among FSWs in Shiraz was $4.7 \%$ [8]. Due to dreadful conditions of prisons, inmates are more susceptible to infectious diseases, as shown in a survey conducted on prisoners in Southern Khorasan [9].

There is growing number of studies about HIV infections among high-risk groups in different regions of Iran. However, many of these studies result in different or occasionally contradictory conclusions; therefore, the generalizability of any single study to all its sub-groups is limited. Considering the enormous number of drug users and increasing trend of extramarital sex among Iranian youth [10], the aim of this study was an attempt to provide comprehensive and reliable epidemiological characteristics of HIV infection among high-risk groups in Iran, to assist developing prevention strategies for policy makers, and to guide further research within this field.

\section{Material and methods}

\section{Search strategy}

A comprehensive literature search of international electronic bibliographic databases was performed, including PubMed, Scopus, EMBASE and Science Direct and National databases, with Magiran, Iranmedex, and SID from inception to November 20, 2016. In addition, to identify further relevant studies, hand searches were also performed.

Key search terms included terminology for "Prostitute", "FSW" or "Sex Worker", "Intravenous Drug Users", "Drug Addicts", "IDU” or "Injection Drug Users", "Prisoner", "Jail", "Inmate” or "Prison", "HCV”, "Human Immunodeficiency Virus" or "Blood-Borne Infection" and "Iran". Studies restricted to those performed in 2000 and after, and all published studies in English and Persian languages conducted in Iran were considered for the study. The reason studies have been reviewed from 2000 onwards was that HIV is an emerging disease and serological studies on high-risk groups, such as prisoners, have been considered in recent years in Iran.

We defined sex work as exchanging sex for money, drugs, or goods [2]. Also, IDUs were defined as people who inject narcotic substances into the body with a hollow needle and a syringe, which is pierced through the skin into the body, usually intravenously [11]. We only included articles that determined HIV infection in patients by laboratory criteria according to country guideline definitions [12]. Case reports, case series, letters to the editors, review articles, animal studies, and conference records were excluded from the study.

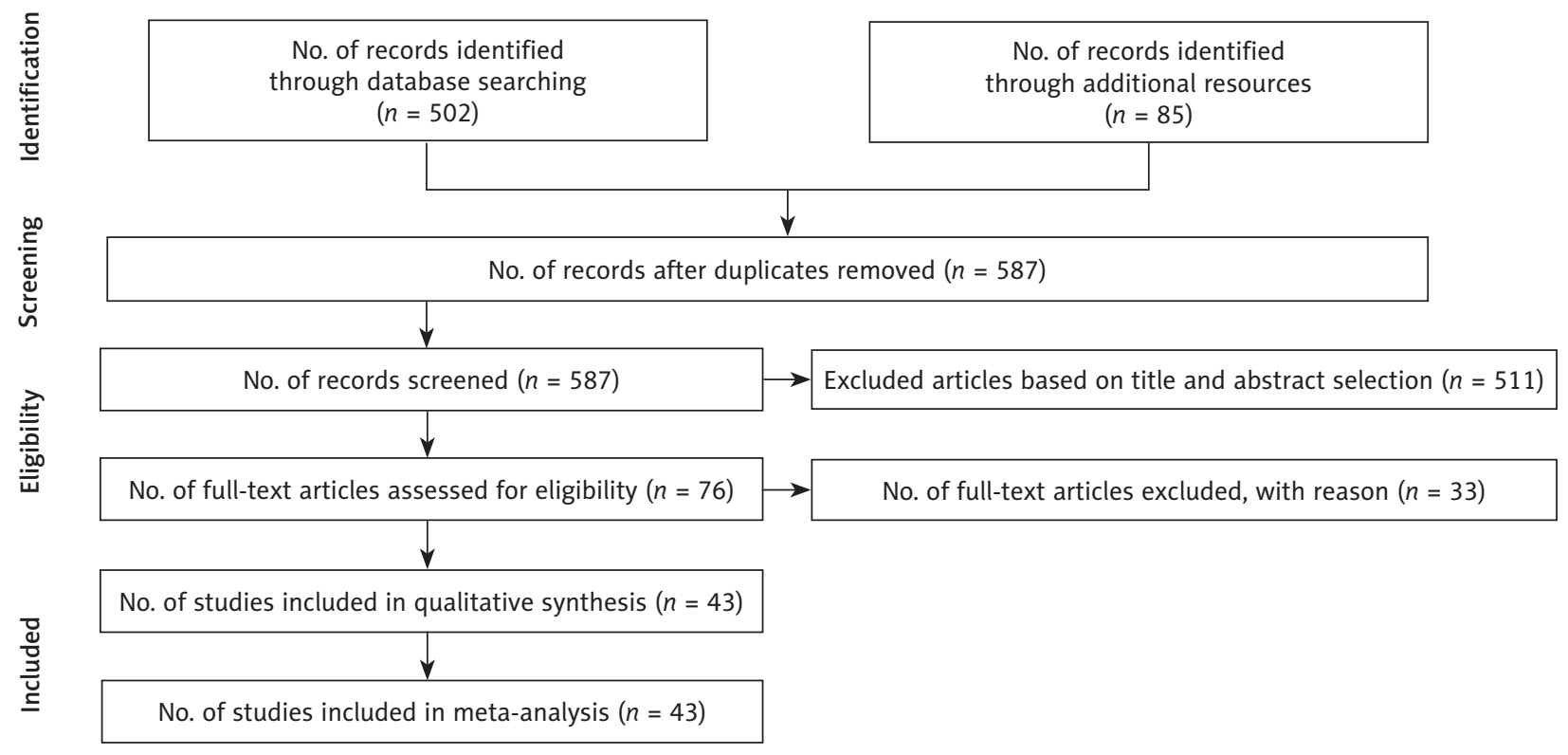

Figure 1. Flow diagram of the meta-analysis 
Table 1. Description of the studies included in the meta-analysis

\begin{tabular}{|c|c|c|c|c|c|c|c|}
\hline $\begin{array}{l}\text { First author } \\
\text { (year) }\end{array}$ & $\begin{array}{l}\text { Sample } \\
\text { size }\end{array}$ & Location & $\begin{array}{l}\text { High-risk } \\
\text { group }\end{array}$ & $\begin{array}{l}\text { Recruitment } \\
\text { setting }\end{array}$ & Recruitment method & Age group & Gender \\
\hline $\begin{array}{l}\text { Mirahmadizadeh } \\
\text { et al. (2000) }\end{array}$ & 1,061 & Shiraz & IDUs & Camp & Census & $34.4 \pm 8.5$ & Male \\
\hline $\begin{array}{l}\text { Khani et al. } \\
\text { (2003) }\end{array}$ & 346 & Zanjan & $\begin{array}{c}\text { Drug addict } \\
\text { prisoners }\end{array}$ & Prison & N.A. & $33.7 \pm 10.2$ & Male \\
\hline $\begin{array}{l}\text { Naderi et al. } \\
(2004)\end{array}$ & 144 & Tehran & IDUs & Hospital & Census & $26.0-30.0$ & Both \\
\hline $\begin{array}{l}\text { Rowhani Rahbar } \\
\text { et al. (2004) }\end{array}$ & 101 & Mashhad & IDUs & Prison & Convenience sample & 32.8 & Male \\
\hline $\begin{array}{l}\text { Ghanbar Zadeh } \\
\text { et al. (2004) }\end{array}$ & 199 & Birjand & Prisoners & Prison & Volunteers & $35.0 \pm 12.3$ & Female \\
\hline $\begin{array}{l}\text { Alizadeh et al. } \\
(2005)\end{array}$ & 427 & Hamadan & $\begin{array}{c}\text { Drug addict } \\
\text { prisoners }\end{array}$ & Prison & $\begin{array}{l}\text { Random number } \\
\text { generator }\end{array}$ & N.A. & Both \\
\hline $\begin{array}{l}\text { Zamani et al. } \\
(2006)\end{array}$ & 207 & Tehran & IDUs & DIC & Consecutive sample & Median, 32 & Male \\
\hline $\begin{array}{l}\text { Azarkar et al. } \\
(2006)\end{array}$ & 400 & Birjand & Prisoners & Prison & $\begin{array}{l}\text { Stratified random } \\
\text { sampling }\end{array}$ & $34.1 \pm 11.7$ & Both \\
\hline $\begin{array}{l}\text { Talaie et al. } \\
(2007)\end{array}$ & 214 & Tehran & Drug addicts & Hospital & Sequential sampling & $37.9 \pm 14.9$ & Both \\
\hline $\begin{array}{l}\text { Saleh et al. } \\
(2007)\end{array}$ & 94 & Hamadan & IDUs & $\begin{array}{l}\text { Forensic } \\
\text { medicine }\end{array}$ & Census & N.A. & Both \\
\hline $\begin{array}{l}\text { Sodbakhsh et al. } \\
(2007)\end{array}$ & 60 & Tehran & IDUs & Hospital & Census & $35.3 \pm 9.7$ & Male \\
\hline $\begin{array}{l}\text { Mashkati et al. } \\
\text { (2007) }\end{array}$ & 98 & Isfahan & IDUs & $\begin{array}{c}\text { Behavioral } \\
\text { consulting } \\
\text { canter }\end{array}$ & Census & $30.0-40.0$ & Male \\
\hline $\begin{array}{l}\text { Afsar Kazerooni } \\
\text { et al. (2007) }\end{array}$ & 360 & Shiraz & IDUs & Community & Random sampling & $33.0 \pm 7.3$ & Male \\
\hline $\begin{array}{l}\text { Amin-Zadeh et al. } \\
(2007)\end{array}$ & 70 & Tehran & IDUs & Hospital & Volunteers & $34.4 \pm 9.6$ & Male \\
\hline $\begin{array}{l}\text { Tajbakhsh et al. } \\
\text { (2007) }\end{array}$ & 600 & Shahre kourd & Prisoners & Prison & Census & 25.4 & Male \\
\hline $\begin{array}{l}\text { Pourahmad et al. } \\
\text { (2007) }\end{array}$ & 1,431 & $\begin{array}{c}\text { Isfahan, } \\
\text { Lorestan } \\
\text { Chaharmahal }\end{array}$ & Prisoners & Prison & N.A. & $25.0-60.0$ & Male \\
\hline $\begin{array}{l}\text { Khodabakhshi } \\
\text { et al. (2007) }\end{array}$ & 121 & Gorgan & $\begin{array}{l}\text { Drug addict } \\
\text { prisoners }\end{array}$ & Prison & Random sampling & N.A. & Both \\
\hline $\begin{array}{l}\text { Imani et al. } \\
(2008)\end{array}$ & 133 & Shahre kourd & IDUs & $\begin{array}{c}\text { Voluntary } \\
\text { rehabilitation } \\
\text { center }\end{array}$ & Census & $31.3 \pm 7.1$ & Both \\
\hline $\begin{array}{l}\text { Sharif et al. } \\
(2009)\end{array}$ & 200 & Kashan & IDUs & Hospital & Volunteers & $36.5 \pm 10.2$ & Both \\
\hline $\begin{array}{l}\text { Mirahmadizadeh } \\
\text { et al. (2009) }\end{array}$ & 936 & Shiraz & IDUs & DIC & $\begin{array}{c}\text { Systematic random } \\
\text { sampling }\end{array}$ & $33.1 \pm 8.9$ & Both \\
\hline Alavi et al. (2009) & 142 & Ahvaz & IDUs & Hospital & N.A. & $26.3 \pm 5.7$ & Both \\
\hline $\begin{array}{l}\text { Mirzendehdel } \\
\text { et al. (2010) }\end{array}$ & 118 & Tehran & Drug addicts & DIC & Census & $35.1 \pm 1.2$ & Female \\
\hline $\begin{array}{l}\text { Mohamad-Khani } \\
\text { et al. (2010) }\end{array}$ & 220 & Tehran & IDUs & MMT center & Census & N.A. & Both \\
\hline
\end{tabular}


Table 1. Cont.

\begin{tabular}{|c|c|c|c|c|c|c|c|}
\hline $\begin{array}{l}\text { First author } \\
\text { (year) }\end{array}$ & $\begin{array}{l}\text { Sample } \\
\text { size }\end{array}$ & Location & $\begin{array}{l}\text { High-risk } \\
\text { group }\end{array}$ & $\begin{array}{l}\text { Recruitment } \\
\text { setting }\end{array}$ & Recruitment method & Age group & Gender \\
\hline $\begin{array}{l}\text { Zamani et al. } \\
(2010)\end{array}$ & 118 & Isfahan & IDUs & Community & Peer-driven sampling & $29.0 \pm 6.6$ & Both \\
\hline $\begin{array}{l}\text { Kheirandish et al. } \\
\text { (2010) }\end{array}$ & 459 & Tehran & IDUs & Prison & Census & N.A. & Male \\
\hline $\begin{array}{l}\text { Hosseini et al. } \\
(2010)\end{array}$ & 417 & Tehran & IDUs & $\begin{array}{c}\text { Temporary } \\
\text { detention } \\
\text { center }\end{array}$ & Census & N.A. & Male \\
\hline $\begin{array}{l}\text { Ghasemian et al. } \\
(2011)\end{array}$ & 88 & $\begin{array}{c}\text { Sari, } \\
\text { Ghaemshahr }\end{array}$ & IDUs & Hospital & Census & $35.01 \pm 11.5$ & Both \\
\hline $\begin{array}{l}\text { Navadeh et al. } \\
(2012)\end{array}$ & 177 & Kerman & FSWs & RDS & $\begin{array}{l}\text { Responding driven } \\
\text { sampling }\end{array}$ & 30.8 & Female \\
\hline $\begin{array}{l}\text { Moradi et al. } \\
(2012)\end{array}$ & 118 & Hamadan & IDUs & Prison & Peer-driven sampling & $32.0 \pm 8.1$ & Male \\
\hline $\begin{array}{l}\text { Majidi et al. } \\
(2012)\end{array}$ & 104 & Tehran & IDUs & Hospital & N.A. & & Both \\
\hline $\begin{array}{l}\text { Nokhodian et al. } \\
(2012)\end{array}$ & 161 & Isfahan & Prisoners & Prison & Census & $34.5 \pm 11.2$ & Female \\
\hline $\begin{array}{l}\text { Sofian et al. } \\
(2012)\end{array}$ & 153 & Arak & Prisoners & Prison & Census & $30.7 \pm 5.9$ & Male \\
\hline $\begin{array}{l}\text { Sajadi et al. } \\
\text { (2013) }\end{array}$ & 872 & Countrywide & FSWs & N.A. & Facility-based survey & 31.6 & Female \\
\hline $\begin{array}{l}\text { Khajehkazemi } \\
\text { et al. (2013) }\end{array}$ & 2,290 & Countrywide & IDUs & Combined & $\begin{array}{l}\text { Facility-based } \\
\text { sampling }\end{array}$ & $34.6 \pm 8.9$ & Male \\
\hline $\begin{array}{l}\text { Navadeh et al. } \\
(2013)\end{array}$ & 4,536 & Countrywide & Prisoners & Prison & $\begin{array}{c}\text { Multistage random } \\
\text { sampling }\end{array}$ & N.A. & Both \\
\hline $\begin{array}{l}\text { Kazerooni et al. } \\
(2014)\end{array}$ & 278 & Shiraz & FSWs & RDS & $\begin{array}{l}\text { Respondent-driven } \\
\text { sampling }\end{array}$ & $32.9 \pm 8.7$ & Female \\
\hline $\begin{array}{l}\text { Ramezani et al. } \\
\text { (2014) }\end{array}$ & 100 & Arak & IDUs & MMT center & Census & $17.0-58.0$ & Male \\
\hline $\begin{array}{l}\text { Alihoseinpoor } \\
\text { et al. (2014) }\end{array}$ & 679 & Khoram Abad & IDUs & Camp & N.A. & 34.7 & Both \\
\hline $\begin{array}{l}\text { Zamani et al. } \\
\text { (2014) }\end{array}$ & 305 & Alborz & IDUs & $\begin{array}{c}\text { Drug } \\
\text { treatment } \\
\text { centers }\end{array}$ & N.A. & $25.0-34.0$ & Both \\
\hline Ziaei et al. (2014) & 881 & $\begin{array}{l}\text { Southern } \\
\text { Khorasan }\end{array}$ & Prisoners & Prison & Random sampling & $34.7 \pm 11.4$ & Both \\
\hline $\begin{array}{l}\text { Salehi et al. } \\
\text { (2015) }\end{array}$ & 1,327 & Shiraz & Drug addicts & DIC & Census & 33.4 & Both \\
\hline $\begin{array}{l}\text { Moayedi-Nia } \\
\text { et al. (2015) }\end{array}$ & 161 & Tehran & FSWs & N.A. & $\begin{array}{l}\text { Respondent-driven } \\
\text { sampling }\end{array}$ & $37.4 \pm 8.9$ & Female \\
\hline $\begin{array}{l}\text { Malekinejad et al. } \\
(2015)\end{array}$ & 544 & Tehran & IDUs & RDS & $\begin{array}{l}\text { Respondent-driven } \\
\text { sampling }\end{array}$ & $36.5 \pm 9.2$ & Both \\
\hline
\end{tabular}

\section{Data extraction and quality assessment}

Two independent authors (SK and KM) reviewed the retrieved studies, and the following information was extracted: 1) name of the first author; 2) year of publica- tion and location of study conduction; 3) total sample size; 4) reported prevalence of infection; 5) recruitment setting; 6) recruitment method; 7) age group; 8) high-risk group (IDUs, FSWs, or prisoners). Kappa statistics (95\%) was used to identify the inter-authors reliability. The third au- 


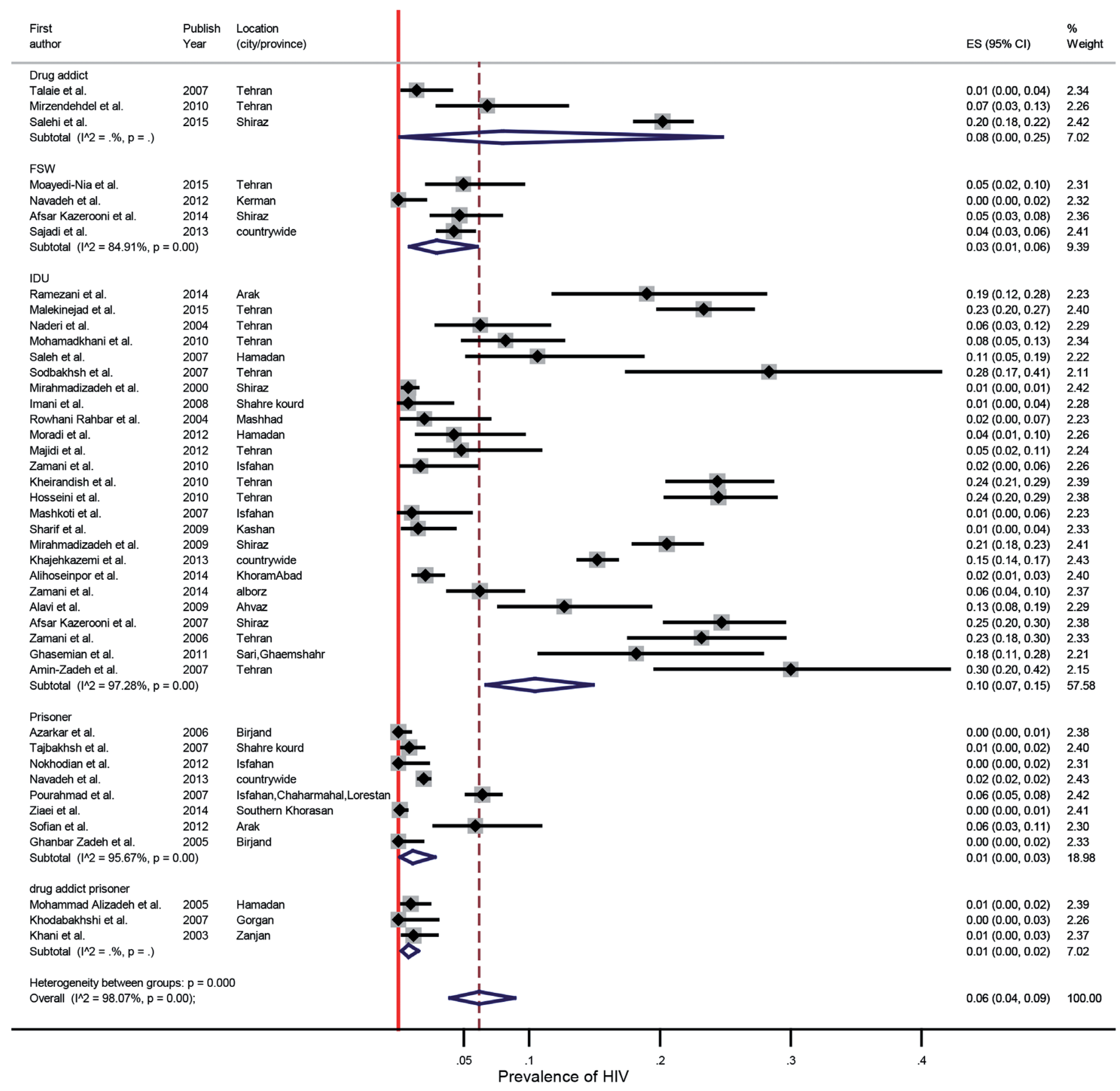

Figure 2. Forest plot of the prevalence of HIV infection in high-risk groups in Iran

thor (EA) was considered as arbiter to resolve any disagreements. STROBE statement was applied to assess the quality of studies.

\section{Statistical analysis}

At first, the variance of each study was calculated through the variance of binomial distribution, given that the prevalence rate has a binomial distribution. Then, each study was given a weight, and was inversely proportional to the variance.

The heterogeneity of results across the studies was checked using Cochran's Q test (with $p$-value $<0.10$ ), and it was quantified by $I^{2}$ statistic. The $I^{2}$ statistic greater than $50 \%$ was considered as significant heterogeneity across the studies. Tau-squared $\left(t^{2}\right.$ or $\left.\mathrm{Tau}^{2}\right)$ statistic and Egger's linear regression test were used to investigate the between-study variance and to examine publication bias, respectively. For 
Table 2. Meta-analysis of the prevalence of HIV infection based on high-risk groups in different geographic area of Iran

\begin{tabular}{|c|c|c|c|c|c|c|c|}
\hline \multicolumn{2}{|c|}{ Geographic location } & $\begin{array}{l}\text { No. of study } \\
\text { (sample size) }\end{array}$ & $\begin{array}{c}\text { Drug addicts } \\
\text { (range) }\end{array}$ & $\begin{array}{l}\text { FSWs } \\
\text { (range) }\end{array}$ & $\begin{array}{l}\text { IDUs } \\
\text { (range) }\end{array}$ & $\begin{array}{c}\text { Prisoners } \\
\text { (range) }\end{array}$ & $\begin{array}{c}\text { Drug addict } \\
\text { prisoners } \\
\text { (range) }\end{array}$ \\
\hline & North & $2(209)$ & - & - & $\begin{array}{c}0.18 \\
(0.10-0.28)\end{array}$ & - & $\begin{array}{c}0 \\
(0.00-0.03)\end{array}$ \\
\hline & West & $6(1,806)$ & - & $\begin{array}{c}0.06 \\
(0.02-0.14)\end{array}$ & - & $\begin{array}{c}0.01 \\
(0.00-0.02)\end{array}$ & - \\
\hline & South & $6(4,139)$ & $\begin{array}{c}0.2 \\
(0.18-0.22)\end{array}$ & $\begin{array}{c}0.02 \\
(0.01-0.04)\end{array}$ & $\begin{array}{c}0.12 \\
(0.00-0.36)\end{array}$ & - & - \\
\hline & Center & $22(6,017)$ & $\begin{array}{c}0.03 \\
(0.01-0.05)\end{array}$ & $\begin{array}{c}0.05 \\
(0.02-0.10)\end{array}$ & $\begin{array}{c}0.11 \\
(0.06-0.17)\end{array}$ & $\begin{array}{c}0.02 \\
(0.00-0.07)\end{array}$ & - \\
\hline & East & $4(1,581)$ & - & - & $\begin{array}{c}0.02 \\
(0.00-0.07)\end{array}$ & - & - \\
\hline
\end{tabular}

detecting source of heterogeneity, sub-groups analysis was conducted on the basis of infection type, high-risk group, and geographical regions. To examine the impact of moderator variables on prevalence rate, meta-regression analysis was used.

In order to estimate a weighted-mean estimate of prevalence for mentioned infections across the included studies, prevalence estimates by each study were pooled using a random-effects meta-analysis model at a confidence level of 95\%. All meta-analysis and meta-regression were performed with Stata software version 12 (StataCorp, College Station, TX, USA). PRISMA statement was utilized as a guide to enhance quality reporting of the review [13].

\section{Results}

The results of the literature search and the selection process are showed in Figure 1. A total of 1,113 potentially rel- evant articles were identified from the initial search. After removing duplicates, 587 articles remained and then, out of which 511 articles were excluded by screening titles and abstracts. Finally, 43 studies [8, 9, 12, 14-53] met eligibility criteria for meta-analysis, which involved 1,746 HIV-positive patients.

\section{Study characteristics}

Studies' characteristics and results are displayed in Table 1 and Figure 2. These studies were published between 2000 and 2015. The sample size of included articles varied from 70 to 4,536 , with a total of 21,450 cases with high-risk behavior, including FWS (3 studies), IDUs (25 studies), prisoners (8 studies), drug addicts ( 3 studies), and drug addict prisoners (3 studies). In five studies, the prevalence rate of HIV/ AIDS among high-risk groups were $0 \%$, and the highest prevalence was related to Amin-Zadeh et al. among IDUs in Tehran (30\%) [52]. 
A

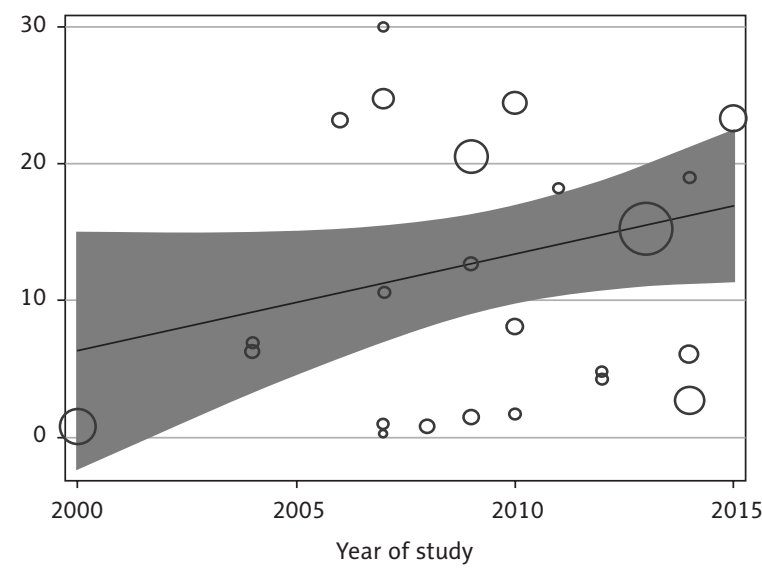

B

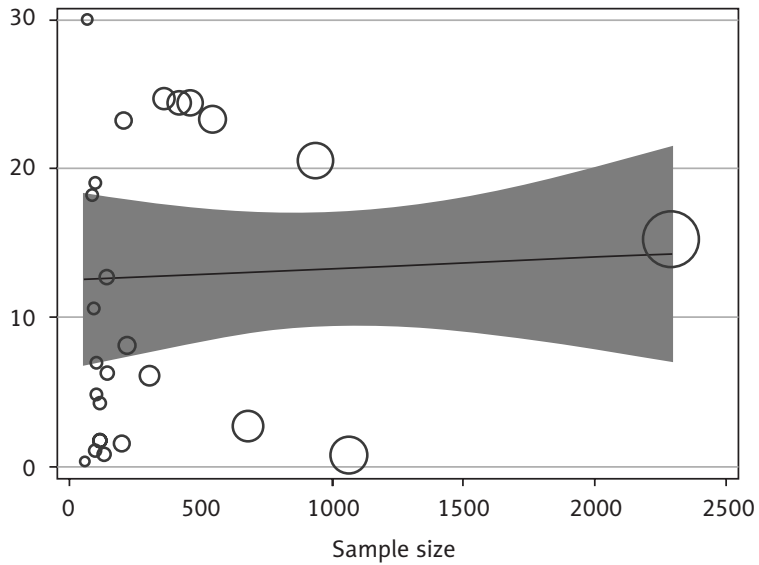

Figure 3. Meta-regression plots of change in prevalence of HIV among IDUs according to changes in years of study and sample size

\section{Evaluation of heterogeneity and meta-analysis}

The results of Cochran's Q test and $I^{2}$ statistics suggested a significant heterogeneity among the included studies ( $\left.\mathrm{Q}=2178.92, \mathrm{df}=42, p<0.001, I^{2}=98.07 \%\right)$. The pooled prevalence of HIV infection in high-risk groups was $0.06 \%$ (95\% CI: 0.04-0.09\%). In order to reduce the heterogeneity, we performed sub-group analysis based on geographical region (3 countrywide study were excluded) (Table 2). Accordingly, the prevalence of HIV among high-risk groups was ranged from 0 among drug addict prisoners in the North to 0.2 (95\% CI: 0.018-0.22\%) among drug addicts in the South parts of Iran.

\section{Meta-regression}

The results of meta-regression analysis are shown in Figure 3. The prevalence of HIV among IDUs was not related to the year of study, and mild increasing trend in this period was not significant $(\mathrm{B}=0.44, p=0.43)$. also, the prevalence of HIV among IDUs was not related to study sample size $(p=0.55)$.

\section{Discussion}

The present systematic review on HIV cross-sectional studies in Iran was conducted on 43 studies, including 25 studies on injection drug users (IDUs), 4 studies on female sex workers (FSWs), and 11 studies on prisoners. The estimated pooled HIV prevalence was $0.06 \%$ in these high-risk groups, ranging from $0.01 \%$ in prisoners, who use drugs, to $0.2 \%$ in IDUs.

We found that only 4 studies have been conducted on female sex workers in Iran, reporting a prevalence of $0.02 \%$ in the South to $0.06 \%$ in the West of the country. Although female sex workers have long been understood to be a key affected population, the extent of their disproportionate risk for HIV infection had not yet been documented appropriately.
We found a great deal of heterogeneity in studies regarding HIV prevalence among FSWs. Such heterogeneity reflect various social, political, economic, and cultural factors within every country [54], yet an understanding of how these factors contribute to HIV acquisition; however, transmission risks has only recently been noticed. On the other hand, changes in macro-structural context and policies (such as sex work decriminalization) as well as features of FSWs' work environment are urgently needed.

Although the prevalence of HIV among FSWs in Iran are comparably low, responses for HIV epidemic, such as free condom campaigns, community empowerment, campaigns to address stigma, and structural policy support are highly recommended [55].

Our systematic review on the prevalence of HIV among IDUs in Iran yielded a pooled prevalence of 0.18 . Injecting drug use is an important cause of HIV transmission. Globally, around 13 million people inject drugs, and 1.7 million of them are living with HIV [55]. On the other hand, HIV is an important contributor to the burden of drug use and has the potency to spread to a wider community through sexual transmissions [56]. There are a few effective interventions addressing HIV in IDUs, including provision of clean needles and syringes (typically through needle and syringe programs; NSPs) to avoid HIV transmission by sharing contaminated injecting equipment, and treatment of opioid dependence with opioid substitution therapy (OST), particularly methadone and buprenorphine, leading to a reduction of drug injection practices [57]. Opioid substitution therapy (OST) and the distribution of sterile needles/ syringes are fundamental and core components of HIV prevention efforts. However, for various IDUs populations, the coverage could be increased by delivering these interventions through several models, rather than relying on one delivery model. For instance, expansion of both pharmacy and NSP distribution of needles/ syringes, establishment of special clinics, and office-based delivery of OST are some of the combined responses. Condom provi- 
sion, instead, could be off paramount importance since sexual transmission of HIV is also a risk for IDUs, and therefore interventions have a maximum effect when they are delivered in combination [58]. Given the challenges of further reducing HIV infection rates and developing an effective vaccine [30], it is critical to focus on behavioral prevention efforts that are based on the best available scientific evidence. Modification of HIV-risk behaviors requires high-risk populations to understand the mechanism of HIV transmission. Without such comprehension, HIV prevention attempts (especially provision of clean needles/ syringes) could be completely useless. Furthermore, provision of ART might also have a role in primary HIV prevention, specifically in IDU populations as well as for people with high-risk sexual encounters [58].

There are some limitations to generalize the results of this review to the whole country. Firstly, sampling of marginalized populations often were carried out using convenient schemes from various locations, including prisons, drug treatment centers, and harm reduction clinics. Secondly, lacking information from many parts of the country affects generalizability of the study at national level. Another limitation is that most studies have been carried out in high-risk areas and settings like prisons, hospitals, or behavioral counseling centers, where the clients have special profile of risky behaviors.

In summary, studies on HIV prevalence in key populations (i.e., high-risk groups) are still lacking in Iran. More complete data is needed to improve the response to HIV epidemic. Moreover, concerted efforts must be launched to gather more reliable and wider information about the epidemic in every part of the country.

\section{Conclusions}

Our results indicate that prevalence of HIV infection among high-risk groups in Iran is low. The prevalence of HIV in high-risk groups in different parts of Iran has a different pattern. Due to significant prevalence of HIV in injecting drug users compared to other high-risk groups, there is a need to pay serious attention to this high-risk group and adopt preventive strategies.

\section{Acknowledgement}

Herewith, we would like to express our appreciation to Dr. Nedjat, Professor of Epidemiology from Tehran University of Medical Sciences for her technical support.

\section{Conflict of interest}

The authors declare no conflict of interest with respect to the research, authorship, and/or publication of this article.

\section{References}

1. Zack MM, Moriarty DG, Stroup DF, Ford ES, Mokdad AH. Worsening trends in adult health-related quality of life and self-rated health - United States, 1993-2001. Public Health Rep 2004; 119: 493.
2. Alter MJ. Epidemiology of viral hepatitis and HIV co-infection. J Hepatol 2006; 44: S6-S9.

3. WHO. HIV/AIDS Fact sheet; 2016. Available at: http://www.who. int/mediacentre/factsheets/fs360/en/ (Accessed: 19.11.2016).

4. Solomon SS, Srikrishnan AK, Mehta SH, et al. High prevalence of HIV, HIV/hepatitis C virus co-infection and risk behaviors among IDUs in Chennai, India: a cause for concern. J Acquir Immune Def Syndr (1999) 2008; 49: 327.

5. Inciardi JA, Surratt HL, Kurtz SP. HIV, HBV, and HCV infections among drug-involved, inner-city, street sex workers in Miami, Florida. AIDS Behav 2006; 10: 139-147.

6. Dolan K, Kite B, Black E, Aceijas C, Stimson GV. HIV in prison in lowincome and middle-income countries. Lancet Infect Dis 2007; 7: 32-41.

7. Zamani S, Kihara M, Gouya MM, et al. High prevalence of HIV infection associated with incarceration among community-based injecting drug users in Tehran, Iran. J Acquir Immune Def Syndr 2006; 42: 342-346.

8. Kazerooni PA, Motazedian N, Motamedifar M, et al. The prevalence of human immunodeficiency virus and sexually transmitted infections among female sex workers in Shiraz, South of Iran: by respondent-driven sampling. Int J STD AIDS 2014; 25: 155-161.

9. Ziaee M, Sharifzadeh G, Namaee MH, Fereidouni M. Prevalence of HIV and hepatitis B, C, D infections and their associated risk factors among prisoners in Southern Khorasan Province, Iran. Iranian J Public Health 2014; 43: 229-234.

10. Haghdoost AA, Mostafavi E, Mirzazadeh A, et al. Modelling of HIV/AIDS in Iran up to 2014. J AIDS HIV Res 2011; 3: 231-239.

11. WHO. Hepatitis B Fact sheet; 2016. Available at: http://www.who. int/mediacentre/factsheets/fs204/en/ (Accessed: 19.11.2016).

12. Ministry of Health and Medical Education. National guideline for HIV/AIDS control and treatment. Tehran: MOHME; 2011.

13. WHO. Hepatitis C Fact sheet; 2016. Available at: http://www.who.int/ mediacentre/factsheets/fs164/en/ (Accessed: 19.11.2016).

14. Khani M, Vakili MM. Prevalence and risk factors of HIV, hepatitis B virus and hepatitis $\mathrm{C}$ virus infections in drug addicts among Zanjan prisoners. Arch Iranian Med 2003; 6: 1-4.

15. Mirahmaizadeh AR, Kadivar MR, Ghane Shirazi R, Fararooei M. Prevalence of HIV infection among intravenous drug addicts in Shiraz, 1998. Journal of Gorgan University of Medical Sciences 2001; 3: 39-42.

16. Rahbar AR, Rooholamini S, Khoshnood K. Prevalence of HIV infection and other blood-borne infections in incarcerated and nonincarcerated injection drug users (IDUs) in Mashhad, Iran. Int J Drug Policy 2004; 15: 151-155.

17. Alizadeh AHM, Alavian SM, Jafari K, Yazdi N. Prevalence of hepatitis $\mathrm{C}$ virus infection and its related risk factors in drug abuser prisoners in Hamedan-Iran. World J Gastroenterol 2005; 11: 4085.

18. Talaie H, Shadnia S, Okazi A, Pajouhmand A, Hasanian H, Arianpoor $\mathrm{H}$. The prevalence of hepatitis B, hepatitis C and HIV infections in non-IV drug opioid poisoned patients in Tehran-Iran. Pakistan J Biol Sci 2007; 10: 220-224.

19. Soudbakhsh A, Nami M, Hadjiabdolbaghi M, Kazemi B. Transfusion transmitted virus prevalence rate in injection drug users (IDUs): a cross sectional study. Tehran University Medical Journal 2008; 66: 113-117 [In Persian].

20. Meshkati M, Taeri K, Etedali E, Farid F. Prevalence of hepatitis B, $\mathrm{C}$ and HIV/AIDS in injecting drug users referred to the Behavioral Diseases Counseling Center in 2004. The first National Congress of infection in drug addicts in Iran; 2007.

21. Afsar-Kazarooni P, Amini-Lari M, Joulaei H, Sabet M, Hasanabadi AR, Naghshvarian M. Surveying the prevalence of acquired viral infection and high-risk behaviors associated with AIDS among injecting drug users in Shiraz. Journal of Fundamentals of Mental Health 2009; 3: 175-184 [In Persian].

22. Tajbakhsh E, Yaghubi R. Serologic evaluation of HIV contamination in Shahrekord prisoners through ELISA and Western blot. Sci J Iran Blood Transfus Organ 2008; 4: 365-368. 
23. Pourahmad M, Javady A, Karimi I, Ataei B, Kassaeian N. Seroprevalence of and risk factors associated with hepatitis $\mathrm{B}$, hepatitis $\mathrm{C}$, and human immunodeficiency virus among prisoners in Iran. Infect Dis Clin Pract 2007; 15: 368-372.

24. Behnaz K, Abdollah A, Fateme F, Mohammadreza R. Prevalence and risk factors of HIV, hepatitis $\mathrm{B}$ virus and hepatitis $\mathrm{C}$ virus infections in drug addicts among Gorgan prisoners. J Med Sci 2007; 7: 252-254.

25. Imani R, Karimi A, Rouzbahani R, Rouzbahani A. Seroprevalence of $\mathrm{HBV}, \mathrm{HCV}$ and $\mathrm{HIV}$ infection among intravenous drug users in Shahr-e-Kord, Islamic Republic of Iran. East Mediterr Health J 2008; 14: 1136-1141.

26. Sharif M, Sherif A, Sayyah M. Frequency of HBV, HCV and HIV infections among hospitalized injecting drug users in Kashan. Indian J Sex Trans Dis 2009; 30: 28-30.

27. Mirahmadizadeh AR, Majdzadeh R, Mohammad K, Forouzanfar M. Prevalence of HIV and hepatitis $\mathrm{C}$ virus infections and related behavioral determinants among injecting drug users of drop-in centers in Iran. Iranian Red Crescent Medical Journal 2009; 11: 325.

28. Alavi SM, Alavi L. Seroprevalence study of HCV among hospitalized intravenous drug users in Ahvaz, Iran (2001-2006). J Infect Public Health 2009; 2: 47-51.

29. Mirzendehdel S, Nadji SA, Tabarsi P, et al. Prevalence of HPV and HIV among female drug addicts attending a drop-in center in Tehran, Iran. Int J Gynecol Obstet 2010; 108: 254-255.

30. Lemckert AA, Goudsmit J, Barouch DH. Challenges in the search for an HIV vaccine. Eur J Epidemiol 2004; 19: 513-516.

31. Zamani S, Radfar R, Nematollahi P, et al. Prevalence of HIV/HCV/ $\mathrm{HBV}$ infections and drug-related risk behaviours amongst IDUs recruited through peer-driven sampling in Iran. Int J Drug Policy 2010; 21: 493-500.

32. Kheirandish P, SeyedAlinaghi S, Hosseini M, et al. Prevalence and correlates of HIV infection among male injection drug users in detention in Tehran, Iran. J Acquir Immune Defic Syndr 2010; 53: 273-275.

33. Hosseini M, SeyedAlinaghi S, Kheirandish P, et al. Prevalence and correlates of co-infection with human immunodeficiency virus and hepatitis $\mathrm{C}$ virus in male injection drug users in Iran. Arch Iran Med 2010; 13: 318-323.

34. Ghasemian R, Najafi N, Amirkhanloo K. The study of infections due to injection drug abuse in the injecting drug users hospitalized at Imam Khomeini Hospital in Sari and Razi Hospital in Ghaemshahr in 2007-2009. J Mazand Univ Med Sci 2011; 21: 9-15 [In Persian].

35. Navadeh S, Mirzazadeh A, Mousavi L, Haghdoost A, Fahimfar N, Sedaghat A. HIV, HSV2 and syphilis prevalence in female sex workers in Kerman, South-East Iran; using respondent-driven sampling. Iranian J Public Health 2012; 41: 60-65.

36. Moradi AR, Emdadi A, Soori B, Mostafavi E. Prevalence of human immunodeficiency virus infection among injection drug users released from jail. Addict Health 2012; 4: 151-155

37. Majidi M. Prevalence of HIV, hepatitis B and C among drug abusers admitted to ICU of Baharloo hospital in 2010. PhD Thesis of Forensic Medicine. Tehran: Tehran University of Medical Sciences; 2012.

38. Nokhodian Z, Yaran M, Adibi P, Kassaian N, Meshkati M, Ataei B. Seroprevalence of hepatitis B markers among incarcerated intravenous drug users. J Res Med Sci 2014; 19 (Suppl 1): S13.

39. Sofian M, Aghakhani A, Banifazl M, et al. Viral hepatitis and HIV infection among injection drug users in a central Iranian City. J Addict Med 2012; 6: 292-296.

40. Khajehkazemi R, Osooli M, Sajadi L, et al. HIV prevalence and risk behaviours among people who inject drugs in Iran: the 2010 National Surveillance Survey. Sex Transm Infect 2013: 89 Suppl 3: iii29-32.

41. Sajadi L, Mirzazadeh A, Navadeh S, et al. HIV prevalence and related risk behaviours among female sex workers in Iran: results of the national biobehavioural survey, 2010. Sex Transm Infect 2013; 89 (Suppl 3): iii37-iii40
42. Navadeh S, Mirzazadeh A, Gouya MM, Farnia M, Alasvand R, Haghdoost AA. HIV prevalence and related risk behaviours among prisoners in Iran: results of the national biobehavioural survey, 2009. Sex Transm Infect 2013; 89 (Suppl 3): iii33-iii36.

43. Ramezani A, Amirmoezi R, Volk JE, et al. HCV, HBV, and HIV seroprevalence, coinfections, and related behaviors among male injection drug users in Arak, Iran. AIDS Care 2014; 26: 1122 1126.

44. Alihoseinpoor M. Prevalence of acquired immunodeficiency virus infection among addicts in compulsory residence center of Khorramabad county. The first international and the fifth national congress of HIV/AIDS; Tehran; 2014.

45. Salehi A, Naghshvarian M, Marzban M, Lankarani KB. Prevalence of HIV, HCV, and High-Risk Behaviors for Substance Users in Drop in Centers in Southern Iran. J Addict Med 2015; 9: 181-187.

46. Moayedi-Nia S, Bayat Jozani Z, Esmaeeli Djavid G, et al. HIV, HCV $\mathrm{HBV}, \mathrm{HSV}$, and syphilis prevalence among female sex workers in Tehran, Iran, by using respondent-driven sampling. AIDS Care 2016; 28: 487-490

47. Malekinejad M, Mohraz M, Razani N, et al. High HIV prevalence in a respondent-driven sampling survey of injection drug users in Tehran, Iran. AIDS Behav 2015; 19: 440-449.

48. Naderi N. Epidemiology of hepatitis C in hospitalized addicts in in Loghman Hakim Hospital, 2000-2001. MD Thesis. Tehran: Shahid Beheshti University of Medical Sciences; 2003.

49. Ghanbarzadeh N, Najafi-Semnani M. A study of HIV and other sexually transmited infections among female prisoners in Birjand. Scientific Journal of Birjand University of Medical Sciences 2006; 13: 69-75 [In Persian]

50. Azarkar Z, Sharifzadeh G, Miraki M. HBV, HCV and HIV prevalence among South Khorasan prisoners. Scientific Journal of Birjand University of Medical Sciences 2007; 14: 50-56 [In Persian].

51. Saleh M, Kazemifar AM, Saleh AE, Asghar A, Nobari H, Samimi R. Prevalence of HIV, hepatitis B and C seropositivity in expired IV drug abusers in Hamedan. Forensic Medicine J 2010; 16: 253-257 [In Persian].

52. Aminzadeh Z, Sarhangi-poor KA. Sero epidemiology of HIV, HBV, $\mathrm{HCV}$ and Syphilis among hospitalized IDUs in Loghman-Hakim hospital. Iranian Journal of Medical Microbiology 2007; 1: 53-56 [In Persian].

53. Mohammadkhani-Ghiasvand A, Golian-Tehrani S, Modanlu S, Vejdani M, Babaei-Heydarabadi A, Dehghankar L. Investigation of serologic prevalence of HIV and hepatitis B infections and its relationship with behavioral risk factors among drug addicts. J Health Syst Res 2016; 12: 70-76.

54. Shannon K, Csete J. Violence, condom negotiation, and HIV/STI risk among sex workers. JAMA 2010; 304: 573-574.

55. Shannon K, Strathdee SA, Goldenberg SM, et al. Global epidemiology of HIV among female sex workers: influence of structural determinants. Lancet 2015; 385: 55-71.

56. Rachlis B, Brouwer K, Mills E, Hayes M, Kerr T, Hogg R. Migration and transmission of blood-borne infections among injection drug users: understanding the epidemiologic bridge. Drug Alcohol Depend 2007; 90: 107-119.

57. Tilson H, Aramrattana A, Bozzette S. Preventing HIV infection among injecting drug users in high-risk countries: an assessment of the evidence; 2007 Available at: http://www.nap.edu/openbook. php? recordid $=11731$ \&page $=1$ (Accessed: 18.02 .2010$)$.

58. Mathers BM, Degenhardt L, Ali H, et al. HIV prevention, treatment, and care services for people who inject drugs: a systematic review of global, regional, and national coverage. Lancet 2010; 375 : 1014-1028. 